\title{
Research on the Ritual of Sharing Sacrificial Food
}

\author{
WU Yu-ping, DU Yan \\ Folklore Institute, East China Normal University, Shanghai, China
}

\begin{abstract}
Sharing sacrificial food refers to the behavior that believers share the food that has been used as sacrificial oblations. This is one of the links of sacrificial rituals and has religious significance. This ritualistic behavior can be traced back to the era when people make a living by hunting. Nowadays, such a behavior still exists in Jiangsu and Zhejiang provinces, and is also regarded as one of the ways to get blessings.
\end{abstract}

Keywords: sharing food, sacrificial food, blessings, gods and ghosts

\section{Introduction}

Sharing food here means people share the food after it has been given to gods or ancestors as sacrificial oblations. Walter Burkert discusses the universality of sharing food used at funerals in his book HOMO NECANS-The Anthropology of Ancient Greek Sacrificial Ritual and Myth. He also mentions that this behavior dated from the era of hunting and its original aim was to better unite people in a community. "Even while mourning the death of Patroklos, Achilles permits his companions to 'feast the heart-pleasing burial'. This unabashed statement refers to behavior that is offensive to anyone concerned merely with the dead individual, yet has not been expunged to this day, namely, that in an environment of grief, pain, and tears, the pleasure of the festive meal will thrive. At first the necessary combination of death and eating appeared only in the hunt.

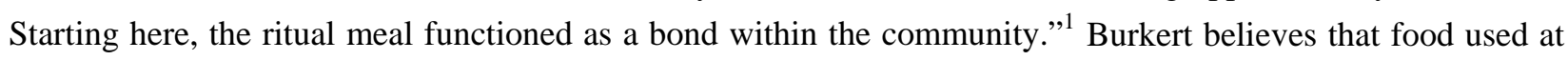
rituals in the hunting era was served as glue between people - the bond that held people together and this was exactly the reason why people later began to share food after sacrificial rituals. So here we will further discuss why food used at rituals has this function.

\section{The Origin and Significance of Sharing Sacrificial Food}

In the hunting era, primitive people believed that everything had a soul and all animals were spirits. However, in order to survive, they had to eat animals or other creatures in nature. Therefore, hunting, killing and eating these natural creatures that have souls had become a thing that people had to do although they knew it should not be done. When eating them, they shared together, thus they feel they could share the sin together. People in the same group did the same behavior or made the same mistake, which let them become more mentally close. They felt like they have a common enemy and were willing to share weal and woe together. Their emotional connections with each other were thus strengthened. After eating, in order to alleviate their guilt of sin, people would take the animal as their totem. Normally, people would absolutely not hunt this

WU Yu-ping, Post-Doctor in Folklore Institute, East China Normal University.

DU Yan, Lecturer in school of Foreign Languages, Shanghai Jiao Tong University.

${ }^{1}$ Walter Burkert, HOMO NECANS-The Anthropology of Ancient Greek Sacrificial Ritual and Myth, Peter Bing (Trans.), Berkeley, Los Angeles, London: University of California Press, p. 50. 
animal. Only in important festivals, they would immolate the animal to hold sacrificial rituals because they believed this creature had spirits and could help people to communicate with gods. As what R. Smith thinks, holding sacrificial rituals at the altar is the essential element in every ancient cult, and that such sacrifice goes back to a killing and eating by the clan of its totem animal, which was regarded as of kin with the clan and its god, and whose killing at ordinary times was therefore strictly forbidden.

Sigmund Freud attributed this kind of behaviour to Oedipus complex in Totem and Taboo. A. L. Kroeber gave an interpretation on Freud's view, "The expelled sons of the primal horde finally banded together and slew their father, ate him, and appropriated the females. In this they satisfied the same hate impulse that is a normal infantile trait and the basis of most neuroses, but which often leads to unconscious 'displacement' of feelings, especially upon animals. At this point, however, the ambivalence of emotions proved decisive. The tender feelings which had always persisted by the side of the brothers' hate for their father, gained the upper hand as soon as this hate was satisfied, and took the form of remorse and sense of guilt... They undid their deed by declaring that the killing of the father substitute, the totem, was not allowed... The totem sacrifice and feast reflected the killing and eating of the father, assuaged 'the burning sense of guilt', and brought about 'a kind of reconciliation' or agreement by which the father-totem granted all wishes of his sons in return for their pledge to honor his life." 2

In The Structure of Chinese Funeral Ceremony-Basic Form, Ceremony Order and Action Primacy of Performance, James L. Watson once said that "If anything is central to the creation and maintenance of a unified Chinese culture, it is the standardization of ritual. To be Chinese is to understand, and accept the view, that there is a correct way to perform rites associated with the life-cycle... What we accept today as 'Chinese' is in large part the product of a centuries-long process of ritual standardization.”3 Malinowski also pointed out that: "Human life contains crisis, emotional disturbance, mental conflict, personality disintegrate... Religious beliefs can help turn positive aspects of mental conflict into traditional standardization. So, religious beliefs meet everybody's needs... On the other hand, religious beliefs and rituals enhance the sustaining force of human solidarity." ${ }^{4}$ Sharing food after sacrifice is not only a traditional Chinese ritual, but also one of the effective ways to unite people. People's spirits and beliefs can be better unified. Just as French sociologist Emile Durkheim said in The Elementary Forms of Religious Life, "So we have here a whole group of ceremonies whose sole purpose is to awaken certain ideas and sentiments, to attach the present to the past or the individual to the group.",

In religious sacrificial rituals, sacrificial oblations are not only one of the communication mediums between man and gods, but also offer a good operating platform for them. Sacrificial oblations, as believers' gifts to gods, are the carrier through which people pray, express their wishes or emotions to gods. They are the way and the method for man and gods to communicate mutually. Sacrificial oblations finally build a bridge between the secular and divine world, and help establish a harmonious and interdependent relationship between

\footnotetext{
2 A. L. Kroeber, Totem and Taboo: An Ethnologic Psychoanalysis, Anthology of 20th Century's Religious Studies and Anthropology in the West, Zong Shi (Ed.), Lidao Song, Dajian Xu (Trans.), etc., (SDX Joint Publishing Company, 1995), p. 44-45 ${ }^{3}$ James L. Watson, The Structure of Chinese Funeral Ceremony-Basic Form, Ceremony Order and Action Primacy of Performance, Journal of History and Anthropology, 1(2).

${ }^{4}$ Bronislaw Malinowski, A Scientific Theory of Culture and Other Essays, Xiaotong Fei (Trans.), Beijing: Huaxia Publishing House, 2002, p. 85.

${ }^{5}$ Emile Durkheim, The Elementary Forms of Religious Life, Dong Qu and Zhe Ji (Trans.), Shanghai: Shanghai People's Publishing House, 1999, p. 498.
} 
man and gods. There are various kinds of sacrificial oblations. There are non-edible substances which are believed to have supernatural powers. For example, the Chinese take "six tools" (Bi, Cong, Gui, Zhang, Hu, Huang), silk and paper money as sacrificial oblations; The Incas take gold bricks, silver ingots, and gold or silver statues as sacrificial oblations; the Egyptians take unprocessed metals and precious stones as sacrificial oblations. Food always occupies a very important position among all sacrificial oblations, because from the believers' world view, gods, like man, need to eat food. The Egyptians believe that gods need man's support to maintain their power, and their main purpose of supplying temples with sacrificial oblations is to help maintain the universe. The gods are very dependent on the food supplied by man. The sacrifices compensate the energy Egyptian gods have consumed in the creation and maintenance of the universe. The gods will become more powerful with more sacrifices offered to them. Therefore, the offering of sacrificial food is what gods care about most. The dead are regarded as gods, and thus sacrificial food is also the key to maintain their vitality. ${ }^{6}$ Once gods eat food people sacrificed, they will not only become powerful themselves, but also will help people to realize their wishes, bless them and help them live a long life.

In return, sacrificial oblations can bring benefits to people. "Sacrificial rituals can turn personal religious experience into the common experience of a group of people, and awaken a group's common religious sentiments. It strengthens the connection between believers and the god they worship, which is to say, strengthens the connection between individuals and the society they belong to. It consolidates and develops a group's common rituals. The main cultural function of common rituals is to show and reconfirm group loyalty. People gather together and hold religious ceremonies in order to further strengthen their consciousness of mutual consent and group cohesion." ${ }^{7}$ Sharing food, as part of sacrificial rituals, also has this function. For a family, "Sharing the food which has been used to sacrifice their ancestors and thus has some 'divinity' will create a sacred atmosphere, making family members continuously strengthen their mutual loyalty and unity. People believe that sacrificing and sharing food in the holy name of ancestors can bring a bright future and ample food and clothing to their families. Therefore, all family members must attend the ceremony." ${ }^{\circ}$ For society, it is good for social stability and can enhance social core cohesion.

Besides, in the view of believers, wine and meat used at sacrificial rituals are considered to be god-given blessings, and thus are also called "Fuji" and "Zuorou" in Chinese, which mean wine and meat with good fortune. People will have good luck and get certain "divinity” once they take in the food that has been eaten by gods. In fact, from the evolution of the Chinese character "Fu", we can find that the original meaning of "Fu" is to make an offering of wine to gods in an attempt to obtain gods' blessings. People believed that gods would bless them if they offered enough wine. Therefore, we find reasonable basis in Philology for the act of making an offering of full wine to gods reverently and calling wine and meat used at sacrificial rituals as "Fuji" and "zuorou". "Through sharing sacrificial oblations, the most intimate communion and communication can be established between man and gods." In this sense, sacrificial food can be called as "sacred food".

\footnotetext{
${ }^{6}$ Bruce G. Trigger, Understanding Early Civilizations: A Comparative Study, Jian Xu (Trans.), Beijing: Peking University Press, 2004, p. 338.

7 Rongfu Chen, Religious Etiquette and Culture, Beijing: Xinhua Publishing House, 1992, p. 3.

8 Qingkun Yang, Religions in Chinese Society, Shanghai: Shanghai People’s Publishing House, 2007, p. 51.

${ }^{9}$ Mariasusai Dhavamony, Phenomenology of Religion, Bingjiang Gao (Trans.), Beijing: People’s Publishing House, 2006, p. 218.
} 


\section{The Spread of Sharing Sacrificial Food as a Custom}

Nowadays, many Chinese ethnic minorities still keep the custom of sharing sacrificial food, although they may have different beliefs. For example, in the big celebration "Qiangli Year" of the Qiang nationality, "after sacrificial rituals, the villagers will cook the goats that have been offered to gods and thus obtain certain 'divinity' from gods, and distribute them in 'dam feast' so that people can share the sacred food together. Sharing 'sacred mutton' 'turned the invisible connection between man and gods into a real bond'. The scapegoats take the sense of guilt hidden in everyone's heart away. The invisible unity of a group and sense of belonging will be evoked from everyone's heart and every member in the group can truly feel it. In fact, the sacred goats will bring the bad things in the hearts of villagers away through sacrificial rituals, while remaining the good things. Sharing 'sacred mutton' in 'dam feast' will create a holy atmosphere, urging every member of a group to continuously strengthen mutual loyalty and unity and to make joint endeavors." 10 The Yi nationality worships fire. For Yi people, the most important ceremony in Torch Festival is "Fire Worship". "Every year, Yi people kill chicken and goats to sacrifice Fire God, praying they could get blessings from Fire God and wishing Fire God could bring luck and happiness to them, protect them from disasters and help them have a good harvest. Sacrificial rituals are usually held by a whole clan or in the whole village and are presided over by a Bimo priest. In the daytime, people erect an altar in the rice field at the entrance to the village. The Bimo priest recites some paragraphs from Worship for Fire God, after which villagers will kill chicken and goats to sacrifice Fire God. In the evening, all villagers eat sacrificial food together. As night falls, the fire ceremony truly starts."11 The custom of sharing sacrificial food in the Qiang and Yi nationalities bears people's good wishes for a wonderful future.

Similarly, it is also a very common custom in Taiwan's ethnic groups. The Taiya people from Taiwan's Gaoshan nationality have many traditional festivals, most of which are associated with farming, such as Reclamation Sacrifice, Warehouse Sacrifice, Weeding Sacrifice and so on. In Harvest Sacrifice, people keep the custom of sharing sacrificial food. "The Harvest Sacrifice is held one day after the Hunting Sacrifice. A priest holds a sickle and prays for a good harvest in the field. He cuts some ears of chestnuts, places the sacrificial food on where he cuts, pours wine on the ground, and then distributes wine and food to every family. Each family holds Fuling Sacrificial ritual separately: they plant bamboo on the ground, use hemp ropes to tie sacrificial food on it, call their ancestors, and finally hold a grand banquet together."12 The custom of eating sacrificial food is not only handed down in ethnic minorities, but also quite popular in the Han nationality. In many areas in the northern part of Jiangsu Province, there is a custom, according to which families will hold a ceremony to comfort the dead on the 42th day after the death of an old man in the family (The ceremony is held on the 42th day because it is believed that on the day the dead will know the fact that they are already dead and their bodies have been cremated). For example, people will invite monks to chant scriptures and pay craftsmen to make "paper houses" for the ceremony. The daughters of the dead (or granddaughters if the dead didn't have a daughter) will buy various (over twenty kinds of) sacrificial foods to sacrifice the dead, including meat dishes

\footnotetext{
${ }^{10}$ Yuhua Zhou, Tingguang Tian: Sharing and Combining: Sharing “Sacred Goats” and the Qiang Nationality’s religious sentiments-Taking “Qiangli Year” in Qionglai Resettlement Area as An Example, Academic Journal of Sichuan Minzu College, 2012(6).

${ }^{11}$ Rui Lu: The Fire Worship of the Yi Nationality and Related Sacrificial Rituals, Official Paper of Yunnan Committee of CPPCC, 2010.

${ }^{12}$ Guoqiang Chen, The Characteristics of the Traditional Festivals of Taiwan's Gaoshan nationality, The Customs of Fujian-Taiwan area's festivals_Collected Essays of the Second Seminar of Fujian Province's Folklore Society, 1991(12).
} 
such as fish, chicken, duck, turtles; vegetables dishes such as mushrooms, broccoli; fruits such as apples, bananas, oranges and so on. This is known as "Replacing Meals". On the 42th day, the daughters prepare the food mentioned above; on the 43rd day, the families share the food that is believed to be able to bring people good fortune (rice will not be eaten because it has been brought to the grave and sacrificed to the dead in advance).

A custom can only develop and spread over the course of many years' accumulation, which is similar to Jiegang Gu's theory, although Gu's theory belongs to a different context. There is a custom in today's Jiangsu and Zhejiang Provinces: On the way to send the dead to the funeral home, people set up an altar on which all kinds of fruits are put and fire firecrackers when passing the dead's daughter's husband's home. Once the hearse leaves, the local people will eat the fruits. The custom is called "Road Sacrifice". The local people will compete with others to get the food and usually give it to their favorite children after returning home. If the dead had lived a long life, more people will try to get the food, because people think eating the food will bring long life to their children. The custom of eating sacrificial food not only exists in ceremonies for the dead, but also in sacrifices for the gods. On 15th August of every year, almost every family will hold traditional moon festival ceremony. On that night, people will prepare a bowl of water, moon cakes, lotus roots, water chestnuts, green soy beans, taros, pomegranates, apples and so on to sacrifice the moon. After the ceremony, people can enjoy the food, especially the water. Usually, people will let their children drink it. Some say children will not wet the bed after drinking the water; some say the water is good for children's eyes. In general, from the facts mentioned above, we can see that there are some reasons behind the act of "eating", most of which are related to "bringing good fortune". The biggest function is blessing the descendants. This behavior also originated from the hunting era.

Regarding eating food sacrificed to gods or ancestors after sacrifices, a lot of descriptions can be found in ancient literature. And the ancients were quite particular about eating sacrificial food. Chu Ci from The Book of Odes which has been mentioned above has the most detailed descriptions about the whole process-from preparing the sacrificial oblations in the beginning to sharing sacrificial food in the end. $C h u C i$ is a poem about worshiping ancestors and gods. It described the whole process of the ritual, from the preparation before sacrifice to the feast after sacrifice, showing us how people in Zhou Dynasty hold sacrificial rituals in detail.

The poem is divided into six chapters. The first chapter is about preparations for the sacrifice. The second chapter begins to describe the scene. The third chapter is the further description of the scene. In the fourth, the priest addressed the ritual on behalf of gods; In the fifth chapter, the ritual was finished. The priest returned to his original place. The emcee declared that gods already got drunk. The "imperial corpse" which accepted the sacrifice on behalf of gods was also put back. The last chapter is about the feast as the ending of the whole ritual. From the six chapters, we can see that gods rely on man's sacrificial oblations, and people also wish to get gods' protection through offering food to them. In the end, people would eat sacrificial food because the food has spirits and good fortunes. In Zhou Dynasty, people already had the custom of eating sacrificial food. Therefore, it is no wonder that Mo-tse who lived in the Spring and Autumn period and the Warring States period also had this thought. It well illustrates that Mo-tse had the idea of eating sacrificial food, not in order to saving food as some people think. Beside The Book of Odes, we can also find relevant descriptions in other ancient literature. For example, "Leftovers can not be used as sacrificial oblations, father can not sacrifice son, husband can not sacrifice wife” in The Book of Rites reflects that man can eat food left by gods, but man's leftovers can not be offered to gods and shows the significance of sacrificial food for gods and man. 
In addition to The Book of Odes, eating sacrificial food was also recorded in Mo-tse.

Mo-tse's saying of "if there are no ghosts, sharing food can make people be happier" is often criticized by scholars. Some scholars think this reflects one of Mo-tse's classic thoughts-frugality, and Mo-tse regarded sharing sacrificial food as an act with practical value. ${ }^{13}$ Or they say there is a paradox in Mo-tse's thoughts, because it can be found in Mo-tse's words that he thought sacrificial food would not cause any waste. The food can be sacrificed to gods and spirits if they exist, or be shared by people as a way to strengthen their bonds if not. ${ }^{14}$ People who hold this view obviously do not take sharing sacrificial food as a ritual. They do not understand the important significance of the ritual behaviour for a worshiper like Mo-tse and the religious emotions behind the behavior.

Zhang Taiyan said, "Mo-tse, quite different from Kongzi and Laozi, is a religionist."15 Mo-tse who had a strong religious belief attached great importance to rituals. ${ }^{16}$ Through the analysis above, we have already known the origin and meaning of the ritual of sharing sacrificial food. It can help man to communicate with gods, please gods, get gods' blessings and protection, and is far from a simple daily behavior. It contains a mythological idea. Mo-tse advocated the idea of "ghosts". Eating "sacred food" can prove the existence of gods and ghosts (People eat sacrificial food because they believe it obtains certain "divinity" after eaten by gods and ghosts). This also well supports some of his ideas_- "gods bless the kind and punish the evil”, "gods bless those who respect and serve them" (By eating the food for gods, man can communicate with gods, inform gods of what happened, and help gods distinguish between right and wrong. Gods will also bless people who sacrifice them). Just as Mo-tse said, "it can either obtain fortune from ghost or make people be happier". Moreover, although Mo-tse advocated frugality, he took the sacrificial ritual very seriously. We can also see this from Mo-tse many places. Therefore, making people be happier does not reflect the idea of frugality, but instead reflect Mo-tse's emphasis on rituals. Here the ritual refers to sharing sacrificial food.

The pervasiveness of a ritual can manifest that its existence is very reasonable and also conforms to religious rules. Sharing sacrificial food not only exists in China's classical literature and living ethnography, but also in western countries. The idea of sacrificing, which is the basic doctrine of Christianism, Hinduism, Judaism and Islam, just originated from the custom of sharing meat in tribes and villages in prehistoric age. People who have domesticated flocks and herds shared their meat blood and milk with ancestors and gods, just like the primitive hunters shared preys with each other every day and created a network of mutual benefits in order to prevent jealousy and conflicts and let people enjoy nature's wonderful creatures without violating the invisible rules of the world. ${ }^{17}$ From this we can see that the custom of sharing food with gods has a long history and is widely spread in the western world. Sacrificial rituals are closely associated with food sharing, which can be seen form the meaning of the English word "feast"-in many anthropological works, "having a delicious meal" and "sacrificial festivals" are both expressed through the word "feast"

\footnotetext{
${ }^{13}$ Liangyong Mei, Shilan Yu, Research on Religious Views of Mozi, Mozi Studies Series(10), Qilu Press, 2013 and Jingjin Lu, Study on Mozi's Thoughts about Ghosts and Gods, Master thesis of Guangxi Normal University. In those essays, it is believed that sharing sacrificial food is for practical or utilitarian purposes.

${ }^{14}$ Lei Lei, New Insights into Mozi’s Views on Ghosts and Gods, Journal of Northwest Normal University, 2014(3).

15 Taiyan Zhang, A General Review on Various Schools of Thoughts in Ancient China, Collection of Taiyan Zhang's academic Essays, p. 176.

${ }^{16}$ Whether Mozi's thoughts are religious beliefs or not has been discussed in other Essays, and thus will not be covered again here.

${ }^{17}$ Marvin Harris, Riddles of Food and Culture, Shuxian Ye and Xiaohui Hu (Trans.), Jinan: Shandong Pictorial Publishing House, 2001, p. 21.

${ }^{18}$ Evans-Pritchard, The Nuer-A Modes of Livelihood and Political Institutions of A Nilotic People.
} 
Let's take ancient Greece as an example. Religious ceremonies were an important part of ancient Greeks' religious and secular life. Every city-state of ancient Greece worshiped different gods, which could be their ancestors, heroes who were killed in battles, or those who had made special contributions to their polis. People worshiped them as guardian gods. Although the forms of religious ceremonies held for them were different, their basic structure were similar and included three parts—-parade, sacrifice and sharing sacrificial food. On that day, people went to the holy place where the ceremony was held along a fixed route, and killed cattle, goats and pigs there. They offered some meat to gods as sacrificial oblations, and then share the rest (sometimes people sacrificed the whole animal to gods, and shared them in the end; sometimes people gave bones or blood to gods, and ate the meat together). The ancient Greek historian Herodotus pointed out in History that the Spartans could decide the number of domestic animals used for sacrificial rituals during the war, and they also had the right to keep the skin and meat for themselves. ${ }^{19}$ In ancient Greece, the earliest form of man and gods' food sharing is called "common food institution". Common food institution, as a part of religious ceremonies, helped form a bond between man and gods, gods and things, man and man, man and things by letting man and gods sharing food together. The common food reflected people's inside desires to combine with "others"- the unknowable divinity. ${ }^{20}$ To sum up, the ancient Greeks' "main purpose of holding such rituals is not to just simply present a gift to gods, but to communicate and interact with gods. In the rituals, gods and worshipers formed a bond of kinship by eating the blood and meat of sacrificial animals together.”21 Man and gods' food sharing reflects a characteristic idea of Ancient Greek religion-man and gods have something in common.

\section{Conclusion}

Sharing sacrificial food, as a folk custom originated from the hunting era, has a long history and is widely spread. The continuous ritual reflects people's original and best wishes. The original intention of holding sacrificial rituals is to get blessings from the gods. Since people can not talk with gods directly, sharing sacrificial food becomes the most direct way to communicate with gods as well as the best way to get gods' blessings. Therefore, sharing food is no longer a simple act, but a ritual act with religious significance.

\section{References}

Sun Yirang. (2001). 墨子閑詁. Beijing: Zhonghua Book Company.

Zhan Yinxin. (1992). 神靈與祭祀. Jiangsu: GuJi Chubanshe.

Ruan Yuan. (1980). 十三經注疏. Beijing: Zhonghua Book Company.

He LianKui. (n.d.). 中國禮俗研究. Taiwan: Zhonghua Book Company.

\footnotetext{
${ }^{19}$ Herodotus, Histories, VI, 56

${ }^{20}$ Guangyun Xie, Discuss about the Common Food Institution in Ancient Greece, Teaching of History, 2003(3).

${ }^{21}$ Xiaoqun Wu, Study on Ancient Greek’s Rituals, Shanghai: Shanghai Academy of Social Sciences Press, 2000, p. 75.
} 